\title{
Gas chromatography-mass spectrometry analysis and in vitro biological studies on fixed oil isolated from the waste pits of two varieties of Olea europaea L.
}

\author{
Muna Hayder Abdelrahman ${ }^{1}$, Reem Osama Hussain ${ }^{1}$, Dhulfiqar Sami Shaheed ${ }^{1}$, Majed AbuKhader ${ }^{1,2}$ \\ and Shah Alam Khan ${ }^{1,2, *}$ \\ ${ }^{1}$ Department of Pharmacy, Oman Medical College, Muscat, Sultanate of Oman \\ 2 College of Pharmacy, National University of Science and Technology, Muscat, Sultanate of Oman
}

Received 22 November 2018 - Accepted 2 May 2019

\begin{abstract}
Olive oil isolated from the fruits of the Olea europaea L. is an important part of Mediterranean diet. It is known for its diverse biological actions. Furthermore, a little amount of fixed oil and other bioactive components can also be extracted from the olive seeds which are considered as byproduct of olive oil extraction. Therefore, this study was designed to analyze the fatty acid composition and to perform in vitro biological studies on fixed oil isolated from olive seeds. The fixed oil was isolated from the olive seeds of Syrian and Greek black olive fruits by using Soxhlet apparatus. The purity was checked by measuring its refractive index. Composition of two isolated oils and a commercially available virgin olive oil was determined by preparing their Methyl esters (FAME) followed by GC-MS analysis. Various in vitro assay methods were used to investigate activities such as antioxidant activity by 1,1-diphenyl-2-picrylhydrazyl (DPPH), cytotoxic activity by using Brine shrimps lethality bioassay and antimicrobial activity against two bacterial strains; Staphylococcus aureus and Escherichia coli by agar well diffusion method. GC-MS analysis revealed that the two isolated oils differ quantitatively in chemical composition with oleic acid identified as the major chemical constituent $(62.6 \%$ and $73.56 \%)$. Both the fixed seed oils showed a concentration dependent DPPH radical scavenging activity ranging from 8 to $76 \%$ inhibition. The oils also exhibited excellent cytotoxic activity but no antimicrobial activity was observed. The chemical composition of the isolated fixed olive seed oil is found to be almost similar to the commercially available fruit olive oil. The fixed oil from the seeds of olive fruits possesses useful biological actions. Further studies are needed to isolate and quantify their bioactive constituents.
\end{abstract}

Keywords: antioxidant / antimicrobial / cytotoxic activity / olive oil / olive seeds

\begin{abstract}
Résumé - Analyse par chromatographie en phase gazeuse couplée à la spectrométrie de masse (GC-MS) et études biologiques in vitro d'huiles résiduelles issues des noyaux de deux variétés d'Olea europaea $L$. L'huile d'olive extraite des fruits de l'Olea europaea $L$. constitue une part importante du régime alimentaire méditerranéen. Elle est connue pour ses diverses actions biologiques. En outre, une petite quantité d'huile résiduelle et d'autres composants bioactifs peuvent également être extraits des noyaux d'olive considérés comme des sous-produits de l'extraction de l'huile d'olive. Cette étude a donc été conçue pour analyser la composition en acides gras et réaliser des études biologiques in vitro sur une huile résiduelle isolée à partir de noyaux d'olive. L'huile a été isolée des noyaux d'olives syriennes et d'olives noires grecques à l'aide d'un appareil Soxhlet. La pureté a été vérifiée en mesurant son indice de réfraction. La composition des deux huiles résiduelles et d'une huile d'olive vierge disponible dans le commerce a été déterminée en préparant leurs esters méthyliques (FAME) suivies d'une analyse par GC-MS. Diverses méthodes de dosage in vitro ont été utilisées pour étudier des activités telles que l'activité antioxydante du 1,1-diphényl-2-picrylhydrazyle (DPPH), l'activité cytotoxique à l'aide du dosage biologique de la létalité des larves de crevettes dans l'eau de mer et l'activité antimicrobienne contre deux souches bactériennes (Staphylococcus aureus et Escherichia coli) par la méthode de diffusion sur puits d'agar. Une analyse par
\end{abstract}

\footnotetext{
*Correspondence: sakhan@omc.edu.om
} 
GC-MS a révélé que la composition chimique des deux huiles issues des noyaux d'olive diffère quantitativement, l'acide oléique étant identifié comme le constituant principal (62,6 et 73,56\%). Les deux huiles de noyaux d'olive ont montré une activité de piégeage des radicaux de la DPPH dépendant de la concentration allant de 8 à $76 \%$ d'inhibition. Les huiles présentaient également une excellente activité cytotoxique, mais aucune activité antimicrobienne n'a été observée. La composition chimique de l'huile de graines d'olive résiduelle de noyau est presque identique à celle de l'huile d'olive issue du fruit disponible dans le commerce. L'huile produite à partir des noyaux d'olive possède des actions biologiques utiles. Des études complémentaires sont nécessaires pour isoler et quantifier leurs constituants bioactifs.

Mots clés : antioxydant / antimicrobien / activité cytotoxique / huile d'olive / noyaux d'olive

\section{Introduction}

Olea europaea $\mathrm{L}$. tree belonging to the family Oleaceae is one of the oldest known cultivated crops in the world particularly in Mediterranean region. It is known as Olive in English and Zaitoon in Arabic (Farhangi et al., 2014). The Mediterranean climate is optimal for the cultivation of this small, slow growing but long lived evergreen tree of agricultural importance (Abaza et al., 2015). The olive tree is known for its edible fruit, which is the prime source of olive oil. Olive oil is regarded as a healing agent as well as an excellent food since ancient time. It is consumed regularly as a main source of lipid and hence forms an essential and integral part of Mediterranean diet (Schwingshackl et al., 2017). A number of epidemiological studies have reported that consumption of olive oil promotes good health (GorzynikDebicka et al., 2018) and reduces risk of morbidity and mortality (Cicerale et al., 2009) by protecting against several neurodegenerative disorders (Fung et al., 2009; Scarmeas et al., 2009), cardiovascular diseases (Estruch et al., 2006; Nocella et al., 2018) and certain types of cancer (Dixon et al., 2007; Boss et al., 2016).

The health benefits of consuming Virgin olive oil have been attributed to its high content of a monounsaturated fatty acid (MUFA) namely oleic acid (70-80\% of total fatty acids), and presence of other phenolic bioactive compounds (Caravita et al., 2007; Cicerale et al., 2009; Cioffi et al., 2010). The biological properties of olive oil and its constituents affect health through multiple mechanisms ranging from antioxidant, anti tumour, antimicrobial and modulation of gene functions etc (Rahmani et al., 2014). In traditional system of medicine, olive oil is used to improve digestion, as a laxative, to treat rheumatic pain, colic, to reduce muscle aches, to maintain skin, hair and muscle health (Hashmi et al., 2015). The oil because of its nutritional benefits, stability, delicate flavor, commercial and medicinal value is used in cooking, cosmetics, and pharmaceutical industry (Ghanbari et al., 2012).

The olive seed or pit is obtained as an important by product of olive oil extraction. The olive stone once dumped as a waste material is nowadays used as a source of renewable energy in industrial sector. The main constituents of olive stone are hemicellulose, cellulose and lignin while protein, fat, free sugars are also present in considerable amount (Rodríguez et al., 2008). The olive seed also contains little amount of oil in addition to other bioactive compounds but unfortunately very few studies have been carried out to explore the potential of olive seed oil. We hypothesized that chemical composition of seed oil would be different from the commercial oil extracted from olive pulp and it also possesses useful biological activities. We therefore aimed to (i) analyze and compare the chemical composition of olive seed oil extracted from Greek and Syrian olive fruits variety with that of commercial oil available in market by Gas chromatography coupled with Mass spectrometry (GC-MS) and (ii) investigate the antioxidant, cytotoxic and antimicrobial activity of isolated seeds oil by in vitro methods.

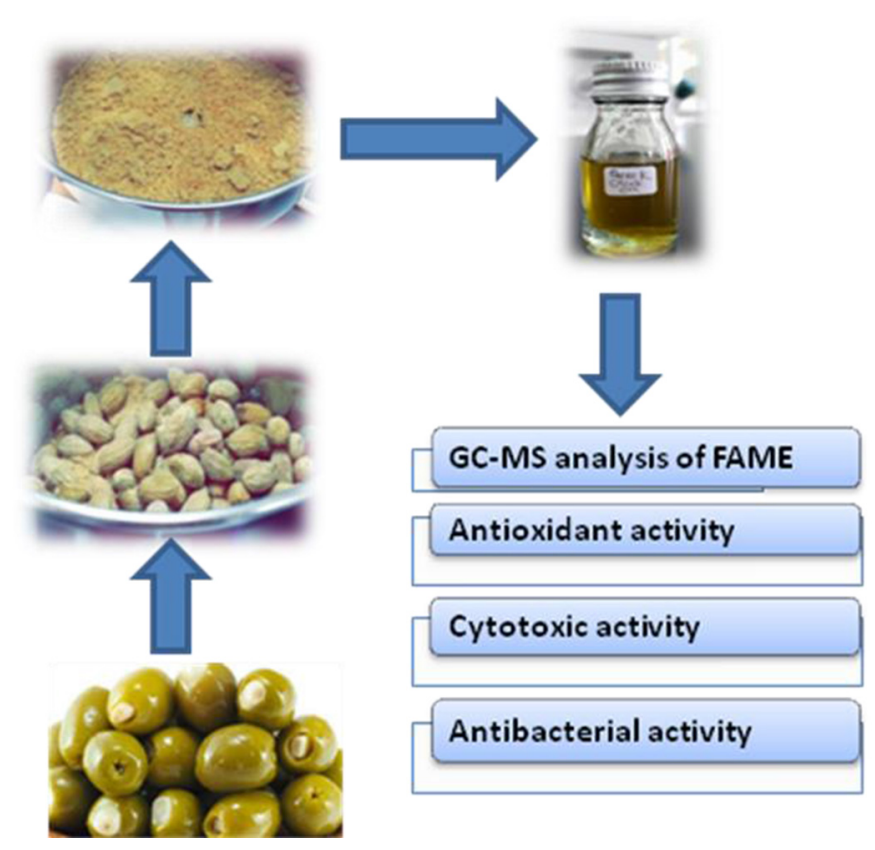

\section{Materials and methods}

\subsection{Chemicals}

All reagents and solvents used in current study were of analytical grade. A commercial olive oil "Rafael Salgado" (RS) was also purchased from the market for comparison purpose. Brine shrimp eggs of San Francisco Bay Brand, USA were used for cytotoxic activity. Escherichia coli (gram negative) and Staphylococcus aureus (Gram-positive), two pathogenic bacterial strains were obtained from the Department of Natural Sciences, Oman Medical College, Sultanate of Oman. 


\subsection{Isolation and extraction of fixed oil from olive pits}

Syrian and Greek black olives were purchased from the local market in the month of June 2016. Whole seeds were separated from the pulp with the help of a knife, cleaned under running water and then dried under the sun. Approximately 250 grams of dry seeds were weighed and pulverized using the domestic blending mixer. The fixed oil from the Syrian and Greek olive seed powder $(150 \mathrm{~g})$ was extracted with the help of petroleum ether solvent $(900 \mathrm{ml})$ by continuous hot extraction method using Soxhlet apparatus at a temperature of $65^{\circ} \mathrm{C}$ for $4 \mathrm{~h}$. The fixed olive seed oil was obtained by removing the excess of solvent from the extract with the help of a rotary vacuum evaporator under reduced temperature and pressure. The oil was transferred into small glass bottles, weighed to calculate percentage yield with reference to dry seed powder and stored at $18^{\circ} \mathrm{C}$ until further use.

\subsection{Preparation of fatty acid methyl esters (FAME) from olive seed oil and virgin oil by Boron trifluoride- methanol method}

The methyl esters of olive oil were prepared as per the reported method with slight modification (Kyriakidis and Dionysopoulos, 1983). Approximately $0.5 \mathrm{~g}$ of oil was dissolved in $6 \mathrm{ml}$ of $2 \% \mathrm{w} / \mathrm{v}$ methanolic sodium hydroxide solution. The mixture was heated under reflux for 10 minutes on a water bath for complete hydrolysis. It was followed by the addition of $7 \mathrm{ml}$ of $14 \%$ boron-trifluoride $\left(\mathrm{BF}_{3}\right)$ solution in methanol to the above mixture and then refluxing for 3 more minutes. After the esterification, $5 \mathrm{ml}$ of heptane was added and the boiling was continued for 2 minutes. The reaction mixture was cooled, diluted with $15 \mathrm{ml}$ of saturated sodium chloride solution and shaken vigorously for few seconds. The supernatant hydrocarbon layer (FAME) was collected and dried over anhydrous sodium sulphate for gas chromatographic (GC) analysis.

\subsection{GC-MS analysis of fatty acid methyl esters (FAME) of the isolated olive seed oil}

GC-MS analysis was performed on a Shimadzu GC-2010 Plus, fitted with a SP-2560 Supelco capillary column $(100 \mathrm{~m} \times 0.250 \mathrm{~mm}$ i.d. $\times 0.2 \mu \mathrm{m}$ film thickness $)$ coupled to GCMS-QP2010 ULTRA MS. Ultra-high purity helium (99.9999\%) from air products was used as carrier gas at a constant flow of $1.0 \mathrm{ml} / \mathrm{min}$. The injection port temperature was kept at $250{ }^{\circ} \mathrm{C}$ while the transfer line and ion source temperatures were maintained at $240^{\circ} \mathrm{C}$. The ionizing energy was $70 \mathrm{eV}$. Electron multiplier (EM) voltage was obtained from autotune. All data were obtained by collecting the fullscan mass spectra within the scan range 35-500 atomic mass unit (amu). The injected sample volume was $1 \mu l$ with a split ratio of 30:1. The oven temperature program was $50^{\circ} \mathrm{C}$ (hold for 5 minutes) and accelerated at a rate of $4{ }^{\circ} \mathrm{C} / \mathrm{min}-250^{\circ} \mathrm{C}$ hold for 5 minutes.

The unknown compounds were identified by comparing the spectra obtained with mass spectrum libraries (NIST 2011 v.2.3 and Wiley, 9th edition)and further confirmed with Supelco 37 component FAME mixture (cat.\# 47885-U).

\subsection{Determination of physico-chemical properties}

The $\lambda \max , \mathrm{pH}$ and refractive index of the two isolated seed oils and RS commercial oil were measured at the room temperature by using double beam UV-spectrophotometer, digital $\mathrm{pH}$ meter and Abbe- refractometer, respectively.

\subsection{In vitro antioxidant activity}

The in vitro antioxidant activity of the fixed oil was determined by using 1,1-diphenyl-2-picrylhydrazyl (DPPH) radical scavenging assay method as described by Al-Hakmani et al. (2013) with slight modification (Al-Hakmani et al., 2013). Briefly, the DPPH solution $(0.04 \mathrm{mg} / \mathrm{ml})$ and different concentrations of oil $(20,40,80$ and $160 \mathrm{mg} / \mathrm{ml})$ were prepared in ethyl acetate. In each test tube, $1 \mathrm{ml}$ of the test sample of different concentrations was mixed with $2 \mathrm{ml}$ of DPPH and shaken for two minutes. The test tubes were covered with aluminum foil and kept aside in the dark for $30 \mathrm{~min}$. The color intensity (optical density) of each solution was measured at $517 \mathrm{~nm}$ using double beam spectrophotometer. Similarly, a blank solution was prepared by substituting the test sample with $1 \mathrm{ml}$ of ethyl acetate. The percent inhibition of DPPH radical was calculated using the standard formula and reported as mean \pm standard deviation of the triplicate reading. The $\mathrm{EC}_{50}$ value for each sample was also determined.

\subsection{Cytotoxic activity of olive oil by Brine shrimp lethality Bioassay}

Brine shrimp (Artemia salina) eggs were hatched in sea water filled in a clean plastic container (Hamidi et al., 2014). The container was partially covered and kept at room temperature for $36 \mathrm{~h}$. The hatched and matured nauplii were attracted to the wall of the container by placing a lamp above the open side. Cytotoxic activity of the olive oils at three different concentrations $(1000,100$ and $10 \mu \mathrm{g} / \mathrm{ml})$ was evaluated following the standard procedure of Sarah et al. (2017). Briefly, the stock solution was prepared by dissolving $20 \mathrm{mg}$ of oil in $2 \mathrm{ml}$ ethyl acetate. An accurately measured quantity of stock solution $(500,50$ and $5 \mu \mathrm{l})$ was transferred to the cleaned and labeled test tubes containing 10 shrimp larvae and the final volume was made up to $5 \mathrm{ml}$ with sea water to obtain the desired concentrations of 1000,100 and $10 \mu \mathrm{g} / \mathrm{ml}$, respectively. The test tubes were incubated for $24 \mathrm{~h}$ and the total number of dead larvae was counted to calculate the percentage mortality for each concentration. The experiment was performed in a triplicate.

\subsection{Evaluation of antimicrobial activity}

Antibacterial activity of the isolated fixed oils was determined by well diffusion method using standard Muller Hinton agar (MHA) media against $S$. aureus and E. coli bacterial strains (Al-Aamri et al., 2018). Wells of approximately $5 \mathrm{~mm}$ diameter were made in Petri plates using sterile borer followed by the addition of 5 and $10 \mu$ of each neat oils to these wells under aseptic conditions. Ampicillin $(25 \mu \mathrm{g} /$ disc) was used as a positive control. The plates were incubated at $37^{\circ} \mathrm{C}$ for $24 \mathrm{~h}$ and then the diameter of zone of inhibition 
M.H. Abdelrahman et al.: OCL 2019, 26, 28

Table 1. Physiochemical properties of fixed oil isolated from olive pits.

\begin{tabular}{|c|c|c|c|c|c|c|}
\hline Oil type & \multicolumn{2}{|c|}{ Refractive index(RI) at } & $\mathrm{pH}$ & $\lambda_{\max }$ & Color & $\begin{array}{l}\text { Percent yield } \\
\text { w/w }\end{array}$ \\
\hline RS Commercial oil & 1.4658 & 1.4677 & 4.82 & 270 & Yellowish green & - \\
\hline Greek seed oil & 1.4686 & 1.4705 & 5.82 & 268 & Light green & 2.66 \\
\hline Syrian seed oil & 1.4667 & 1.4686 & 4.95 & 267.2 & Light green & 2.33 \\
\hline
\end{tabular}

around the well was measured in mm. All experiments were performed in triplicate.

\section{Results and discussion}

\subsection{Percentage yield and physicochemical properties of isolated fixed oil}

The percentage yield of fixed oils extracted was calculated on the dried powder weight of seeds used for extraction. The Greek and Syrian olive pits yielded $2.66 \% \mathrm{w} / \mathrm{w}$ and $2.33 \% \mathrm{w} / \mathrm{w}$ of fixed oil. The percentage yield was found to be slightly lower than the reported values in the literature (Banat et al., 2013). The percentage yield could have been affected by olive variety, less effective penetration of solvent, duration of extraction, harvesting time, size of pits, etc used for extraction. The isolated oils were of light green color and were observed to be less darker and viscous than the RS commercial virgin oil, hence showed a slight difference in $\lambda_{\max }$ values (Tab. 1). The $\mathrm{pH}$ of both the isolated oils and a positive control RS commercial olive oil was found to be acidic (4.82-5.82). However, the commercial oil was more acidic (4.82) suggesting a difference in fatty acids composition and content of oils. The refractive index of all the three oils was computed at $20^{\circ} \mathrm{C}$ by using the following formula:

$$
\eta^{20^{\circ}}=\eta^{\text {observed temp }}{ }^{\circ}+0.00045\left(\text { Observed temp at } 20^{\circ} \mathrm{C}\right) \text {. }
$$

The refractive index of the olive oils (1.4677-1.4705) was found to be in agreement with the reported ranges for virgin olive oil (Codex Alimentarius, 2009).

\subsection{Chemical composition of fixed oil by GC-MS analysis}

GC-MS is widely used to study the fatty acid composition and to detect the adulteration of olive oil and other vegetable oils. The fatty acid methyl esters (FAME) of olive oils were prepared as per the standard method to obtain the sharp peaks in GC chromatogram (Ichihara and Fukubayashi, 2010). The content and composition of the isolated oils and commercial olive oil identified by GC-MS analysis (Figs. 1a-1c) are presented in Table 2. A total of 13 fatty acids methyl esters were identified in the Greek seed oil while the Syrian and commercial olive oils showed presence of 12 and 8 fatty acids respectively. Oleic acid (18:1 Cis 9), a monounsaturated fatty acid was identified as the major component in all the three oils which constituted $61.75 \%$ of the commercial oil, $62.61 \%$ of the Greek oil and $73.56 \%$ of the Syrian oil. The health benefits of olive oil are partially attributed to the high content of this monounsaturated $\omega-9$ fatty acid. The commercial olive oil had the highest amount of saturated palmitic acid $(18.81 \%)$ as compared to the seed oils $(11.60 \%$ and $7.70 \%)$. The polyunsaturated fatty acids (linoleic acid, 18:2 and linolenic acid, 18:3) content of commercial oil was $8.62 \%$ and $3.38 \%$ while linoleic acid could not be detected in either of the seed fixed oils. Amongst the oils, only commercial one showed the presence of $\omega-6$ fatty acid but seed oils showed slightly higher level of $\omega-3$ fatty acids. The Syrian variety contained the highest amount of linolenic acid (4.99\%) followed by Greek oil $(3.96 \%)$. The results of our study are in agreement with literature that olive oil contains higher amount of unsaturated fatty acids (UFA) (Poulli et al., 2006) but interestingly the Syrian variety had the highest level of UFA (83.07\%) followed by commercial olive oil $(76.94 \%)$ indicating it to be more nutritious and beneficial for daily use as an edible oil. The olive seed oils fatty acid composition was also found similar to the type I virgin oil i.e. high content of olive oil and low concentration of linoleic and palmitic acid (Fig. 2) (Diraman and Dibeklioglu, 2009; Asık and Özkan, 2011). The Syrian seed oil might also be more beneficial in reducing the risk of coronary heart disease due to high proportionate values of $\mathrm{C} 18$ : C16 and UFA: SFA (Tab. 3) (Grundy, 1986).

\subsection{Antioxidant activity using DPPH}

Olive oil has been shown to possess good antioxidant activity which is attributed to the presence of different classes of chemical compounds (Kiralan et al., 2009). A simple, popular and reliable in vitro DPPH colorimetric assay was employed to evaluate the free radical scavenging activity of isolated oils. The average $\%$ inhibition of commercial olive oil used as a reference ranged from 9.44 to $65.55 \%$, while the Syrian and Greek oils showed \% inhibition from 14.72 to $76.24 \%$ and 8.06 to $43.41 \%$, respectively tested at concentration of $20-160 \mathrm{mg} / \mathrm{ml}$. It was observed that free radical scavenging activity of oils increased with an increase in concentration (Tab. 4). The Syrian oil exhibited better antioxidant activity than the commercial virgin oil at all concentrations. It has been reported that antioxidant capacity of olives is related to their type, location and maturity (Yildiz and Uylaser, 2015).

\subsection{Cytotoxic activity of olive oil using Brine shrimps}

Olive oil has been reported to have protective role against cancer (Fabiani et al., 2006). The Brine Shrimp lethality (BSL) bioassay is a rapid, inexpensive, simple and comprehensive test for cytotoxicity evaluation for the bioactive compounds. (Asaduzzaman et al., 2015). Hence, BSL bioassay was used to investigate the cytotoxicity of the fixed oils. All oils showed concentration dependent cytotoxic activity. The \% mortality 

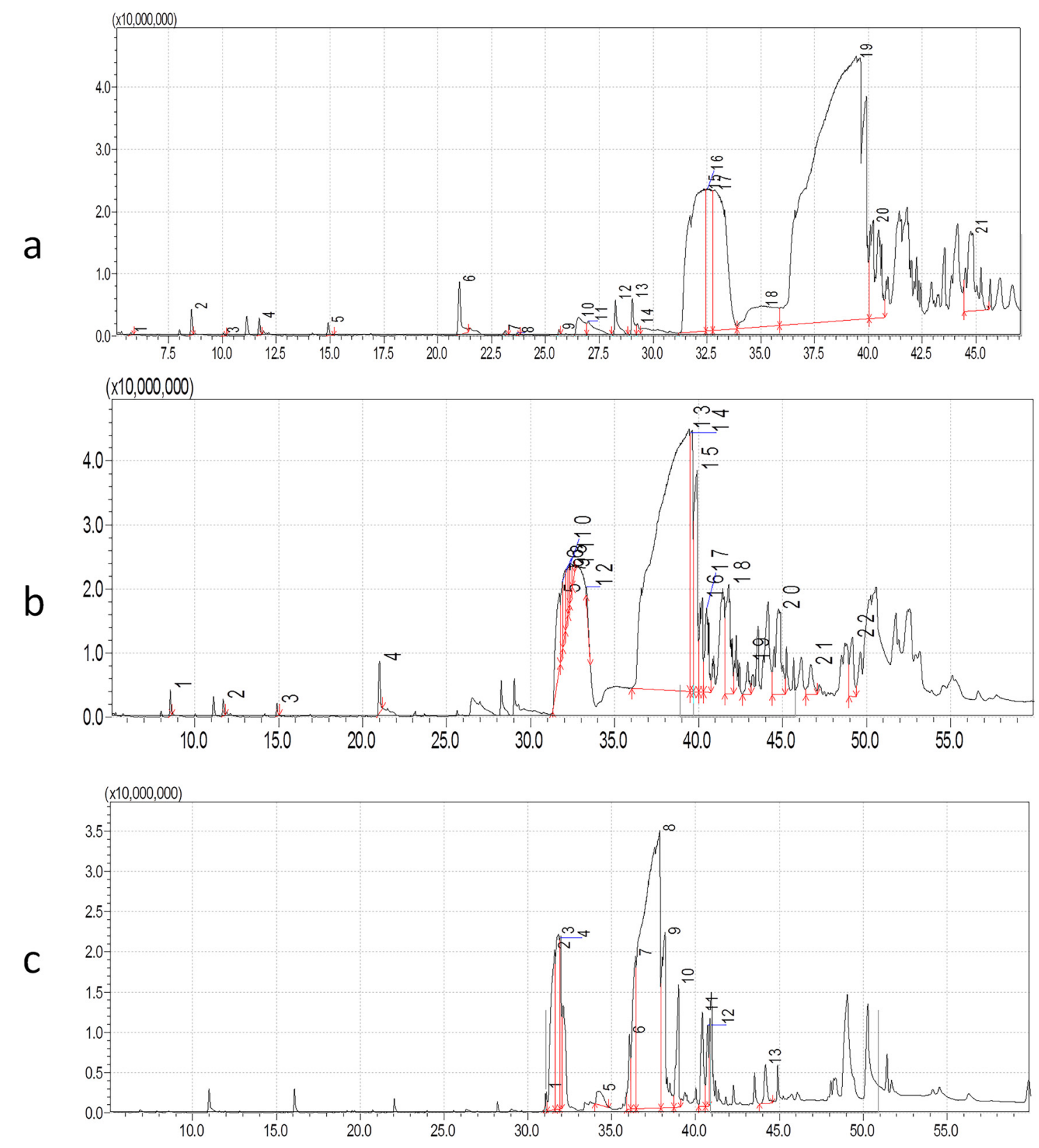

Fig. 1. a: GC chromatogram of Greek olive seed oil; b: GC chromatogram of Syrian olive seed oil; c: GC chromatogram of commercial olive oil.

rate for the oils was observed in the following order; Greek $>$ Commercial RS $>$ Syrian. Greek seed oil caused mortality was $46.7,50.0$ and $80.0 \%$ at 1000,100 and $10 \mu \mathrm{g} / \mathrm{ml}$. At the same concentrations, the RS oil showed percent mortality of 50.0, 60.0 and $73.3 \%$ while Syrian seed oil was the least cytotoxic with \% mortality rate of $63.3,66.7$ and $73.3 \%$. The $\mathrm{LC}_{50}$ values of oils are given in Table 5 .

\subsection{Antimicrobial activity by agar well diffusion method}

Agar well diffusion method was used to screen the in vitro antimicrobial activity of two different concentrations (5 and $10 \mu \mathrm{l}$ ) of the 3 olive oils against two types of bacteria, E. coli (gram negative) and S. aureus (gram positive). Surprisingly, no antimicrobial activity was observed for the isolated oils against the tested bacterial strains. Though, there are conflicting reports about their antibacterial activity. In a similar study conducted by Charu et al. olive oil failed to inhibit the growth of bacteria and no zone of inhibition was observed against the same bacterial strains (Charu et al., 2008).

\section{Conclusion}

The chemical composition of the isolated fixed olive seed oils is found to be almost identical to that of commercial fruit olive oil but a slight difference in physicochemical properties 
Table 2. Fatty acid analysis of isolated oils by GC-MS.

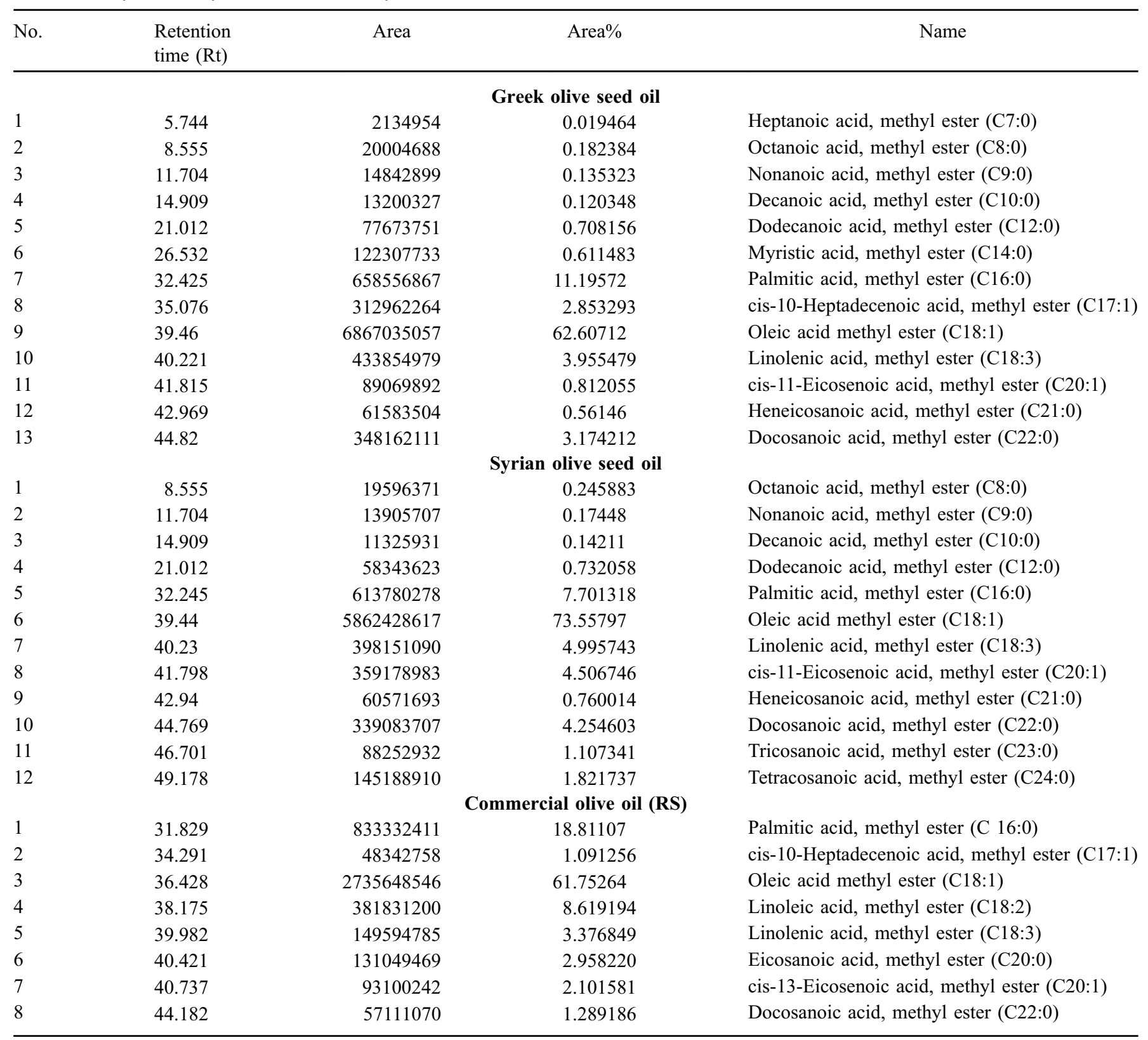

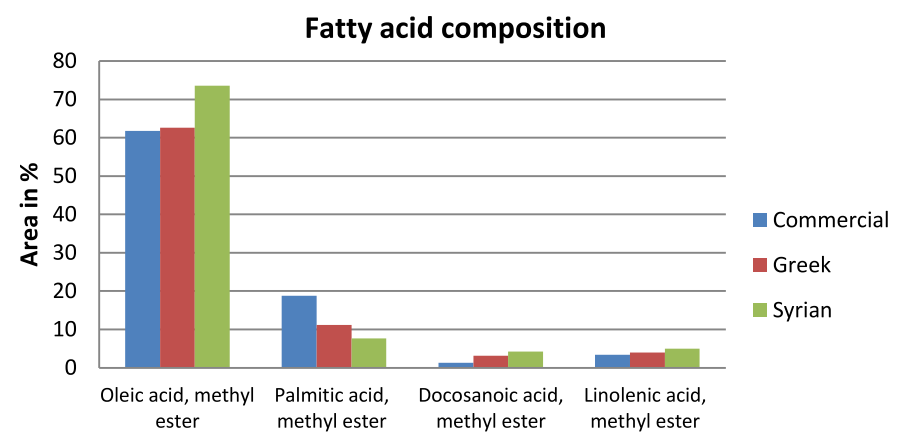

Fig. 2. Comparison of fatty acid composition of commercial and isolated oils from seeds. was noted. The refractive index of the isolated oil is similar to the reference sample and is in agreement with the reported values in the literature but they showed slightly higher $\mathrm{pH}$ and little lower percentage yield and $\lambda_{\max }$ values with respect to the commercial olive oil. These differences are most probably due to the factors such as such as time of harvesting, climate, environmental and soil conditions. However, olive seeds oils were found to contain high content of monounsaturated fatty acids and the Syrian olive seed oil showed promising antioxidant as well cytotoxic potential. Thus, the oil from the waste seeds can be used as an additional economical and alternative source of olive oil. It can also be added to our diet to prevent progression of cardiovascular and neurodegenerative 
Table 3. Fatty acid composition of olive oils.

\begin{tabular}{llcr}
\hline Parameter & RS olive oil & Syrian olive seed oil & Greek olive seed oil \\
\hline Mono unsaturated fatty acid (MUFA) & $64.94 \%$ & $78.07 \%$ & $66.27 \%$ \\
Poly unsaturated fatty acid (PUFA) & $12.0 \%$ & $5.0 \%$ & $3.96 \%$ \\
Saturated fatty acid (SFA) & $23.06 \%$ & $16.93 \%$ & $29.77 \%$ \\
Unsaturated fatty acid (UFA) & $76.94 \%$ & $83.07 \%$ & $70.23 \%$ \\
C18:C16 ratio & 3.92 & 10.2 & 5.94 \\
MUFA: PUFA ratio & 5.41 & 15.61 & 16.73 \\
UFA:SFA ratio & 3.34 & 4.91 & 2.36 \\
\hline
\end{tabular}

Table 4. Free radical scavenging activity of olive oil by DPPH method.

\begin{tabular}{llll}
\hline Concentration $\mathrm{mg} / \mathrm{ml}$ & & \% Inhibition of DPPH radical \\
\hline & RS olive oil & Syrian olive seed oil & Greek olive seed oil \\
20 & $9.44 \pm 2.60$ & $14.72 \pm 5.66$ & $8.06 \pm 0.24$ \\
40 & $26.77 \pm 1.21$ & $49.65 \pm 4.27$ & $24.86 \pm 7.48$ \\
80 & $32.01 \pm 1.82$ & $58.68 \pm 7.52$ & $36.81 \pm 0.32$ \\
160 & $65.55 \pm 2.20$ & $76.24 \pm 2.90$ & $43.41 \pm 1.07$ \\
$\mathrm{EC}_{50}$ & 119.53 & 75.48 & 172.49 \\
\hline
\end{tabular}

Values are mean $\pm \mathrm{SD}(n=3)$.

Table 5. Mean \% mortality of Brine shrimp larvae by olive oil after $24 \mathrm{~h}$ incubation.

\begin{tabular}{|c|c|c|c|c|c|}
\hline $\begin{array}{l}\text { S. } \\
\text { No. }\end{array}$ & Oil type & \multicolumn{3}{|c|}{ Concentration $(\mu \mathrm{g} / \mathrm{ml})$} & $\begin{array}{l}\mathrm{LC}_{50} \\
(\mu \mathrm{g} / \mathrm{ml})\end{array}$ \\
\hline 1. & Greek olive seed oil & $46.7 \pm 5.8 \%$ & $50.0 \pm 10 \%$ & $80.0 \pm 17.3 \%$ & 171.97 \\
\hline 2. & Syrian olive seed oil & $63.3 \pm 15.3 \%$ & $66.7 \pm 5.8 \%$ & $73.3 \pm 5.8 \%$ & 81.33 \\
\hline 3. & RS olive oil & $50.0 \pm 10 \%$ & $60.0 \pm 17.3 \%$ & $73.3 \pm 5.8 \%$ & 109.8 \\
\hline
\end{tabular}

Values are mean $\pm \mathrm{SD}(n=3)$.

diseases. Further studies are needed to isolate and quantify the bioactive constituents.

Acknowledgements. The authors would like to thank Dean, Oman Medical College and HOD, Pharmacy for providing necessary research facilities to carry out this research work. Authors also thank Mr. Jamal Al Sabahi and Ms. Huda of Sultan Qaboos University for GC-MS analysis.

Conflict of interest. The authors declare that they have no conflicts of interest in relation to this article.

\section{References}

Abaza L, Taamalli A, Nsir H, et al. 2015. Olive Tree (Olea europeae L.) Leaves: Importance and advances in the analysis of phenolic compounds. Antioxidants (Basel) 4(4): 682-698.

Al-Aamri MS, Al-Abousi NM, Al-Jabri SS, et al. 2018. Chemical composition and in-vitro antioxidant and antimicrobial activity of the essential oil of Citrus aurantifolia L. leaves grown in Eastern Oman. J Taibah Univ Med Sci 13(2): 108-112.
Al-Hakmani F, Sokindra K, Khan SA. 2013. Estimation of total phenolic content, in-vitro antioxidant and antiinflammatory activity of flowers of Moringa oleifera. Asian Pac J Trop Biomed 3(8): 623-627.

Asaduzzaman M, Rana MS, Hasan SMR, et al. 2015. Cytotoxic (Brine Shrimp Lethality Bioassay) and antioxidant investigation of Barringtonia acutangula (L.). IJPSR 6(8): 1179-1185.

Asık HJ, Özkan G. 2011. Physical, chemical and antioxidant properties of olive oil extracted from Memecik cultivar. Akademik Gida 9(2): 13-18.

Banat F, Pal P, Jwaied N, et al. 2013. Extraction of olive oil from olive cake using soxhlet apparatus. AJOCT 1(4): 1-8.

Boss A, Bishop KS, Marlow G, et al. 2016. Evidence to support the anti-cancer effect of olive leaf extract and future directions. Nutrients 8(8): 513.

Caravita MA, Benincasa C, De Rose F, et al. 2007. Omega-3/omega6 fatty acids ratio in olive oils from Italian olive varieties. Agro Food Ind Hi Tec 18: 17-18.

Charu G, Amar P, Ramesh C, et al. 2008. Antimicrobial activity of some herbal oils against common food-borne pathogens. Afr $J$ Microbiol Res 2: 258-261. 
Cicerale S, Conlan XA, Sinclair AJ, et al. 2009. Chemistry and health of olive oil phenolics. Crit Rev Food Sci Nutr 49(3): 218-236.

Cioffi G, Pesca MS, De Caprariis P, et al. 2010. Phenolic compounds in olive oil and olive pomace from Cilento (Campania, Italy) and their antioxidant activity. Food Chem 121: 105-111.

Codex Alimentarius. 2009. Codex standards for olive oils, and olive pomace oils. Roma: FAO/WHO, 1981. Codex Stan. 33-1981 (Rev. 1989, 2003).

Diraman H, Dibeklioglu H. 2009. Characterization of Turkish virgin olive oils produced from early harvest olives. J Am Oil Chem Soc 86: $663-674$

Dixon BL, Subar AF, Peters U, et al. 2007. Adherence to the USDA food guide, DASH eating plan, and Mediterranean dietary pattern reduces risk of colorectal adenoma. J Nutr 137: 2443-2450.

Estruch R, Martinez-Gonzalez MA, Corella D, et al. 2006. PREDIMED Study Investigators. Effects of a Mediterraneanstyle diet on cardiovascular risk factors: A randomized trial. Ann Intern Med 145: 1-11.

Fabiani T, De Bartolomeo A, Rosignoli P, et al. 2006. Virgin olive oil phenols inhibit proliferation of human promyelocytic leukemia cells (HL60) by inducing apoptosis and differentiation. $J$ Nutr 136: 614-619.

Farhangi H, Ajilian M, Saeidi M, et al. 2014. Medicinal fruits in holy Quran. Int J Pediatr 2(Supp 4): 89-102.

Fung TT, Rexrode KM, Mantzoros CS, et al. 2009. Mediterranean diet and incidence of and mortality from coronary heart disease and stroke in women. Circulation 119: 1093-1100.

Ghanbari R, Anwar F, Alkharfy KM, et al. 2012. Valuable nutrients and functional bioactives in different parts of olive (Olea europaea L.) A review. Int J Mol Sci 13: 3291-3340.

Gorzynik-Debicka M, Przychodzen P, Cappello F, et al. 2018. Potential health benefits of olive oil and plant polyphenols. Int $J$ Mol Sci 19(3): 686.

Grundy SM. 1986. Comparison of monounsaturated fatty acids and carbohydrates for lowering plasma cholesterol. NEng J Med 314: 745-748.

Hamidi MR, Jovanova B, Panovska TK. 2014. Toxicological evaluation of the plant products using Brine Shrimp (Artemia salina L.) model. Maced Pharm Bull 60(1): 9-18.
Hashmi MA, Khan A, Hanif M, et al. 2015. Traditional Uses, phytochemistry, and pharmacology of Olea europaea (Olive). Evid Based Complement Alternat Med 2015: 29.

Ichihara K, Fukubayashi Y. 2010. Preparation of fatty acid methyl esters for gas-liquid chromatography. $J$ Lipid Res 51 (3): 635-640.

Kiralan M, Bayrak A, Ozkaya MT. 2009. Oxidation stability of virgin olive oils from some important cultivars in East Mediterranean area in Turkey. J Am Oil Chem Soc 86: 247-252.

Kyriakidis NB, Dionysopoulos G. 1983. Preparation of fatty acid methyl esters from olive oil and other vegetable oils using aqueous hydrochloric acid-Methanol. Analyst 108: 738-741.

Nocella C, Cammisotto V, Fianchini L, et al. 2018. Extra virgin olive oil and cardiovascular diseases: Benefits for human health. Endocr Metab Immune Disord Drug Targets 18(1): 4-13.

Poulli KI, Mousdis GA, Georgiou CA. 2006. Synchronous fluorescence spectroscopy for quantitative determination of virgin olive oil adulteration with sunflower oil. Anal Bioanal Chem 386: 157-1575.

Rahmani AH, Albutti AS, Aly SM. 2014. Therapeutics role of olive fruits/oil in the prevention of diseases via modulation of antioxidant, antitumour and genetic activity. Int $J$ Clin Exp Med 7(4): 799-808.

Rodriguez G, Lama A, Rodriguez R, et al. 2008. Olive stone an attractive source of bioactive and valuable compounds. Bioresour Technol 99: 5261-5269.

Sarah QS, Anny FC, Misbahuddin M. 2017. Brine shrimp lethality assay. Bangladesh J Pharmacol 12: 186-189.

Scarmeas N, Luchsinger JA, Schupf N, et al. 2009. Physical activity, diet, and risk of Alzheimer disease. J Am Med Assoc 302: 627-637.

Schwingshackl L, Lampousi AM, Portillo MP, et al. 2017. Olive oil in the prevention and management of type 2 diabetes mellitus: A systematic review and meta-analysis of cohort studies and intervention trials. Nutr Diabetes 7(4): e262.

Yildiz G, Uylaser V. 2015. Profile and total content of phenolics and antioxidant activity of commercial table olives from Turkey. Quality Assur Saf Crops Foods 7(5): 635-642.

Cite this article as: Abdelrahman MH, Hussain RO, Shaheed DS, AbuKhader M, Khan SA. 2019. Gas chromatography-mass spectrometry analysis and in vitro biological studies on fixed oil isolated from the waste pits of two varieties of Olea europaea L. OCL 26: 28. 